\title{
Intermédialités
}

Histoire et théorie des arts, des lettres et des techniques

Intermediality

History and Theory of the Arts, Literature and Technologies

\section{“Arts Once More United”: Bridging Disciplines through Creative Media Research, Toronto, 1953-55}

\section{Michael Darroch}

Numéro 30-31, automne 2017, printemps 2018

cartographier (l’intermédialité)

mapping (intermediality)

URI : https://id.erudit.org/iderudit/1049945ar

DOI : https://doi.org/10.7202/1049945ar

Aller au sommaire du numéro

Éditeur(s)

Revue intermédialités (Presses de l’Université de Montréal)

ISSN

1920-3136 (numérique)

Découvrir la revue

Citer cet article

Darroch, M. (2017). “Arts Once More United”: Bridging Disciplines through Creative Media Research, Toronto, 1953-55. Intermédialités / Intermediality, (30-31). https://doi.org/10.7202/1049945ar
Résumé de l'article

Durant les années 1953-55, la Ford Foundation a financé, à l'Université de Toronto, une expérience inédite d'études intermédiales. Le séminaire Culture and Communication ainsi que le journal Explorations qu'ont dirigés Edmund Carpenter, Marshall McLuhan et Jaqueline Tyrwhitt témoignent ainsi de l'organisation et de l'institutionnalisation des études intermédiales durant les années 1950 et 1960. Le réseau didactique qui prend forme dans l'orbe du financement de la Ford Foundation jette les bases de la recherche créative sur les médias, maintenant devenue un aspect fondamental des programmes d'éducation en arts et en sciences humaines. Cet article retrace les connexions géographiques, disciplinaires, artistiques et organisationnelles qui ont facilité cette expérience éducationnelle. 


\title{
"Arts Once More United": Bridging Disciplines through Creative Media Research, Toronto, 1953-55
}

\author{
MichaEl DARROCH
}

\section{INTRODUCTION}

rom 1953 to 1955 , a group of scholars and graduate students at the University of Toronto undertook a unique program of intermedial study and education. Led by Edmund Carpenter, Marshall McLuhan, and Jaqueline Tyrwhitt, among others, this team held wide-ranging discussions and conducted a series of experiments on differentiating media forms and related patterns of perception during their Culture and Communications graduate seminar (1953-55), which would extend into their jointly edited journal Explorations (1953-1957). The group's faculty members drew on the rich experimental traditions of their different backgrounds to delineate the characteristics of the then "new" media alongside related interpenetrating patterns of communication networks, forms of behaviour, and arts practices.

In keeping with this issue's focus on mapping intermediality, my goal in this article is to chart the assemblage of geographic, disciplinary, artistic, and organizational connections that facilitated this educational experiment. We might think of these as interpenetrations between the experience of scholars from Canada, the United States, and Europe; between areas of interest ranging from Indigenous art and culture to urban architecture, literature to economic history, geography to linguistics; and between clusters of academic and creative exploration as diverse as Bauhaus, the Congrès internationaux d'architecture moderne (CIAM), Cybernetics, and Fluxus. In particular, I trace the experimental character of the Explorations group in its commitment to bridging disciplinary traditions and to challenging silos of university education. In the history of intermedial thinking, the Explorations group

\footnotetext{
${ }^{\mathrm{I}}$ Research for this essay was made possible through the generous support of the Social Sciences and Humanities Research Council of Canada and a 20I5 Visiting Fellowship, Institute for Modern Languages Research, University of London.
} 
"Arts OnCE More United":

BRIDGING DisCiplines THROUGH CREATIVE

MEDiA RESEARCH, 1955-1957

stands out as one of the earliest to combine the study of culture and communication and to theorize the boundaries between media and art forms. While intermediality is not a term that these scholars put forward, they nevertheless committed themselves to a comparative framework for considering specificities of different media and art forms (or, in their eyes, media as art forms) as well as infrastructures of media and communications and all their attendant implications for human language and behaviours. $^{2}$

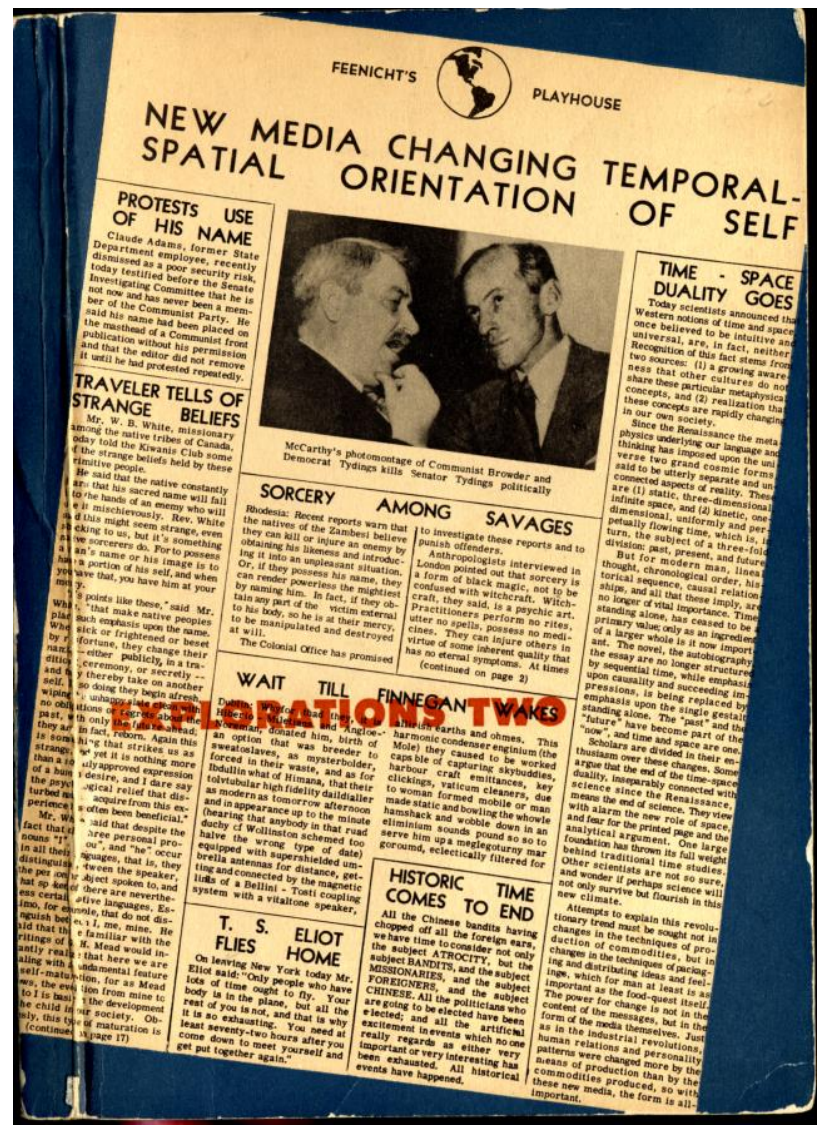

Fig. I. Front cover of Explorations 2 (April 1954). Courtesy of the Estates of Edmund Carpenter and Marshall McLuhan.

2 See also Michael Darroch, "The Toronto School: Cross-Border Encounters, Interdisciplinary Entanglements," in David W. Park and Peter Simonson (eds.), The International History of Communication Studies, New York, Routledge, 2016, p. 276-30I. 
"ARTS ONCE MORE UNITED":

BRIDGING DisCIPLINES THROUGH CREATIVE

MEdia RESEARCH, 1955-1957

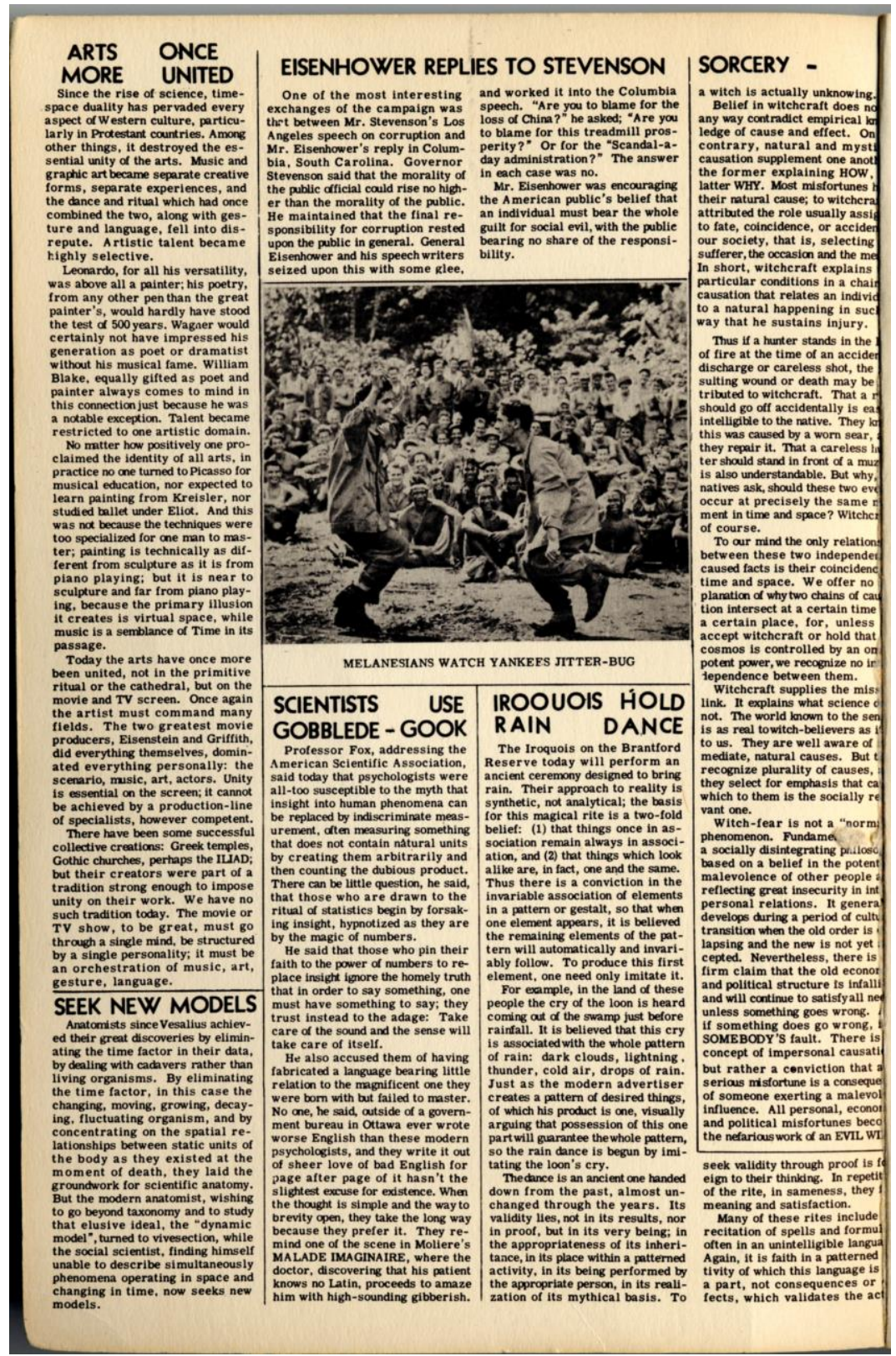

Fig. 2. Inside front cover of Explorations 2 (April 1954). Courtesy of the Estates of Edmund Carpenter and Marshall McLuhan. 
The second issue of Explorations (April 1954) (see Fig. I and 2) exemplified the intrigue, excitement, playfulness, and the experimental character of their intermedial analyses. The issue's covers featured the spoof newspaper Feenicbt's Playbouse (an overt reference to Joyce's spin on London's seventeenth-century Phoenix Playhouse in Finnegan's Wake) with articles detailing their belief that electronic media would lead to a reunification of art forms across genres. Indeed, a discreet entry on the inside back cover announced, “Arts Once More United”:

Since the rise of science, time-space duality has pervaded every aspect of Western culture, particularly in Protestant countries. Among other things, it destroyed the essential unity of the arts. Music and graphic art became separate creative forms, separate experiences, and the dance and ritual which had once combined the two, along with gesture and language, fell into disrepute. Artistic talent became highly selective.

$[\ldots]$

Today the arts have once more been united, not in the primitive ritual or the cathedral, but on the movie and TV screen. Once again the artist must command many fields. The two greatest movie producers, Eisenstein and Griffith, did everything themselves, dominated everything personally: the scenario, music, art, actors. Unity is essential on the screen; it cannot be achieved by a production line of specialists, however competent.

$[\ldots]$

The movie or TV show, to be great, must go through a single mind, be structured by a single personality; it must be an orchestration of music, art, gesture, and language. ${ }^{3}$

94 The launch of network television in Canada was a driving force behind the project. To develop a method of comparison between television and other media forms, one year after the Canadian Broadcasting Corporation (CBC) established its first television stations in Toronto and Montreal in 1952, scholars from five disciplines (anthropology, English, town planning/architecture, psychology, economics) successfully obtained funding from the Ford Foundation, established the two-year Culture and Communications Seminar, and sought a common vocabulary, drawing

${ }^{3}$ Explorations: Studies in Culture and Communication, no. 2, Edmund Carpenter, W. T. Easterbrook, H. M. McLuhan, Jaqueline Tyrwhitt, D. C. Williams (eds.), Toronto, University of Toronto, 1954 . 
on models from each discipline. These scholars were drawn together by the announcement of a new Ford Foundation program in the Behavioral Sciences Division for interdisciplinary research and study. In many ways, the framework of this program was particularly apt to laying the foundations of intermedial education in postwar Canada. The program was geared specifically to bridging disciplinary traditions and required grant holders to establish a regular, formal, or informal seminar involving scholars and graduate students from different disciplines. Riding a wave of postwar universalist philosophy of education, the Ford Foundation thus set the stage for a founding moment in Canadian media studies and the history of "Toronto School" communications research. The program announcement summarized the basic desire to establish institutional parameters for bridging disciplines from a team approach, each member contributing specialized knowledge and perspectives:

Many scientists and scholars engaged in the study of human behavior have expressed concern in recent years with the lack of sufficient intellectual contact between such behavioral sciences as psychology, sociology, and anthropology on the one hand and such related disciplines as history, social and political philosophy, economics and business, law, and humanistic studies on the other. [...] In the conviction that such an effort would advance the study of human behavior, the Behavioral Sciences Division of the Ford Foundation announces a program of support for interdisciplinary research and training of this kind. The program provides for the support of a small number of interdisciplinary studies by faculty members and graduate students who would undertake research projects necessitating contributions from such different fields and who would engage in joint seminars on the particular and general problems of such collaboration. ${ }^{4}$

The University of Toronto put forward three proposals, two from established scholars, but the only successful one emerged from a group of younger and recently appointed professors eager to challenge the hierarchies and taken-for-granted structures of university education.

\footnotetext{
${ }^{4} \mathrm{H}$. Marshall McLuhan Fonds, Library and Archives Canada (hereafter LAC), MG 3I I56 Volume 204, File 26.
} 
"ARTS ONCE MORE UNITED":

BRIDGING DisCiplines THROUGH CREATIVE

MEDiA RESEARCH, 1955-1957

Edmund Carpenter had joined the Anthropology Department in 1948 and would quickly become engaged with $\mathrm{CBC}$ radio before participating in some of the earliest $\mathrm{CBC}$ television programming in 1953. As Heyer has noted, Carpenter, along with Marshall McLuhan, "gives us the raison d'être for medium theory almost 40 years before the emergence of the term." Carpenter had befriended McLuhan, whose 195I book The Mechanical Bride ${ }^{6}$ surveyed the maelstrom of technological change in North America through the lens of advertising and popular culture. They sought out the participation of town planner Jaqueline Tyrwhitt, who had arrived in Toronto from the United Kingdom in late 195I to take up a Visiting Professorship in the School of Architecture. Tyrwhitt was immersed in the UK's networks of architects and town planners associated with Bauhaus and the CIAM. McLuhan in particular enthusiastically welcomed Tyrwhitt's expertise through her affiliation with Sigfried Giedion, CIAM's General Secretary, with whom McLuhan had corresponded since 1939. Giedion's 1948 book Mechanization Takes Command 7 would become a major focus in the seminar the group proposed to the Ford Foundation. ${ }^{8}$ In addition to Giedion, the work of political economist Harold Innis was a singular inspiration in determining the group's research direction. While Innis had died prematurely in 1952 , Thomas Easterbrook, a long-time associate of McLuhan, and a member of the Department of Political Economy, brought Innis's wide-ranging research interests to

5 Paul Heyer, "Live from the Met: Digital Broadcast Cinema, Medium Theory, and Opera for the Masses," Canadian Journal of Communication, vol. 33, no. 4, 2008, p. 594.

${ }^{6}$ Marshall McLuhan, The Mechanical Bride: Folklore of Industrial Man, New York, The Vanguard Press, 195I.

7 Sigfried Giedion, Mechanization Takes Command: A Contribution to Anonymous History, New York, Oxford University Press, 1948.

${ }^{8}$ On the collaborations between Tyrwhitt, Giedion, and the Explorations group see also Michael Darroch, "Bridging Urban and Media Studies: Jaqueline Tyrwhitt and the Explorations Group, 195I-1957," Canadian Journal of Communication, vol. 33, 2008, p. 14769; Michael Darroch and Janine Marchessault, "Anonymous History as Methodology: The Collaborations of Sigfried Giedion, Jaqueline Tyrwhitt, and the Explorations Group (195I55)," in Andreas Broeckmann and Gunalan Nadarajan (eds.), Place Studies in Art, Media, Science and Technology: Historical Investigations on the Sites and the Migration of Knowledge, Weimar, VDG, 2009, p. 9-27; Michael Darroch, "Sigfried Giedion und die Explorations: Die anonyme Geschichte der Medienarchitektur," trans. Johannes Passman, Zeitschrift für Medienwissenschaft no. II, 2014, p. 144-54; Michael Darroch, "Giedion and Explorations: Confluences of Space and Media in Toronto School Theorisation," in Norm Friesen (ed.), Transatlantic Developments in Media and Communication Studies, Basel, Springer International, 2016, p. 62-87. 
"ARTS ONCE MORE UNITED":

BRIDGING DisCiplines THROUGH CREATIVE

MEDiA RESEARCH, 1955-1957

the group. Psychologist David Carlton Williams also joined the initiative, likely at the behest of the then Vice-President of the University of Toronto Claude Bissell, who advocated for the group's proposal and recommended a clear balance between disciplines from the social sciences, humanities, and applied contexts of town planning. (Indeed, Bissell seems to have signed for Williams on the original Ford application. ${ }^{9}$ ) Thus was initiated the two-year Culture and Communications Seminar, one of the first experimental educational endeavours allowing master's and doctoral students to consider culture and communication as joint objects of study. The Ford program resonated directly with other postwar calls for unifying higher education in which the Toronto team was immersed.

\section{INFLUENCES}

Explorations exemplified the group's concern with the biases of specific media, drawn from their close encounters and readings of a range of scholars seeking common problems across disciplines and new forms of unity in educational program development (among others, Innis, Giedion, John Ulric Nef Jr., Karl W. Deutsch, Norbert Wiener, and György Kepes). The journal also featured work by specialists whose studies they believed would lend themselves to the study of new media (for Carpenter these included linguists and anthropologists such as Edward Sapir and A. Irving Hallowell). At the University of Toronto, Innis had clearly shaped the thought of the young group with his work on Canadian economic history and his publications regarding the biases of media forms and communication processes. Inspired by their study of Giedion's histories of space-time across architectural and cultural forms, the group was further concerned with the spatial and temporal conditions in which different media penetrated each other. Giedion in particular was committed to fostering educational environments in which experimentation to test the overlapping boundaries of academic disciplines could take place. In the early 1940s Giedion would seek to connect McLuhan with a range of thinkers, projects, and educational experiments in North America. In a series of letters, Giedion encouraged McLuhan to think broadly, to seek examples in literature and visual arts that define the general cultural trends of their era. Through his histories of architectural space and cultural

${ }^{9}$ Edmund Carpenter, Jaqueline Tyrwhitt, H. M. McLuhan, W. T. Easterbrook, and D. C. Williams, "University of Toronto: Changing Patterns of Language and Behavior and the New Media of Communication," Grant File PA 53-70, Section I, New York, Ford Foundation Archives [hereafter FFA], 1953 [held in the Rockefeller Archive Center, New York], p. II. 
"ARTS ONCE MORE UNITED":

BRIDGING DisCiplines THROUGH CREATIVE

MEDiA RESEARCH, 1955-1957

production, Giedion had long called for establishing a new equilibrium between "thought and feeling," calling upon educational practitioners to establish "faculties of interrelations" across universities. ${ }^{\text {IO }}$

Giedion intended to support McLuhan by putting him in contact with the University of Chicago economic historian John Ulric Nef Jr., who had co-founded the Committee for Social Thought in 194I. Giedion sought such partners in the United States to establish new programs of scholarly and student exchange between Europe and North America. To Giedion's disappointment, Nef wrote to him that the proposal for "a closer post-war contact between scholars, students and countries" would not be readily feasible as his colleagues were preoccupied with work in Chicago and not in a position to commit themselves to a program yet to be established. ${ }^{\text {II }}$ Giedion replied that he had not conceived of a commitment to a program. Rather, he suggested that an "outline for reform and international relation [ships] [...] cannot be tackled by more pedagogues and government officials, but only by creative scholars who have shown in their own work that they are capable to think in terms of methods." ${ }^{12}$ One such scholar was the young McLuhan, whom he recommended to Nef in the same letter. ${ }^{13}$ Although Nef would not be able to provide McLuhan with an academic position, he wrote to him that "I have heard very good things about your work [at Saint Louis University]. I am sure you will agree with me that it is important we should carry on teaching of the kind the Committee on Social Thought sponsors

Io Sigfried Giedion, "A Faculty of Interrelations," in D. Huber (ed.), Wege in die Öffentlichkeit, Zurich, Institut für Geschichte und Theorie der Architektur, 1987, p. 160-63. Originally published in the Michigan Society of Architects Weekly Bulletin, vol. I, 1943, p. I-4.

II Nef to Giedion, 28 May 1943. Zurich, Institut für Geschichte und Theorie der Architektur [hereafter GTA], 43-K-1943-8-3(G).

${ }^{12}$ Giedion to Nef, 3 August 1943, GTA, 43-K-1943-8-3(G).

${ }^{13}$ Giedion wrote to Nef: "One evening at St. Louis, I met a young scholar of English literature, Mr. H. M. McLuhan. I had an excellent impression of this young man who seems to live rather isolated at St. Louis University. I heard that he made his Ph.D. at Cambridge (England) and that he became there a catholic (as f.i. also T.S. Eliot). I did not read any of his articles, but I shall ask him to send me some fragments of his book on English literature, and when they are all right, I shall try and do my best that they will be published by a good publisher. Perhaps, Chicago University may invite him once for a lecture. [...] I guess Mr. McLuhan would fit into the Chicago environment and I did not find many youngsters of his kind of approach. He asked me in St. Louis where I was going, and I told him that I was on my way to Chicago for some research and to meet some friends, to confer with them about an integrated curriculum.” Giedion to Nef, ${ }_{3}$ August 1943, GTA, 43-K-1943-8-3(G). 
"Arts OnCE More United":

BRIDGING DisCiplines THROUGH CREATIVE

MEDiA RESEARCH, 1955-1957

in many places.” ${ }^{14}$ In 1946, McLuhan would make a similar pitch to the University of Chicago's then president Robert Hutchins. ${ }^{\text {Is }}$

The Toronto team was also actively engaged with the work of historian and political cyberneticist Karl W. Deutsch. In his 1950 treatise on "Higher Education and the Unity of Knowledge," Deutsch discusses a range of themes towards building a cohesive program in undergraduate education bridging histories of "science and thought," advocating in the same way that Norbert Wiener had "dreamed for years of an institution of independent scientists working together." ${ }^{16}$ Like Wiener and Giedion, Deutsch viewed the disciplinary specialism championed by current university models to be a threat to establishing peace on an international scale. (In the same year, Deutsch and his colleague Giorgio de Santillana would also join Wiener in proposing a new model of decentralized urbanism to prepare for the potential of atomic warfare. ${ }^{17}$ ) In his 28 March 1951 letter to Wiener, McLuhan remarked that "as a friend and student of Sigfried Giedion, I have paid special attention to your Cybernetics and The Human Use of Human Beings," and further that "a recent encounter with Professor Deutsch's discussion of communication and education led

${ }^{14}$ Nef to McLuhan, H. Marshall McLuhan Fonds, LAC, MG31, Di56, Vol. 32, File 32-52. It is interesting to note that some months later, in November 1943, Nef also attempted to bring Harold Innis to Chicago, several years before Innis and McLuhan would become acquainted in Toronto. Nef wrote: "[T] here is a sort of gambler's chance that we may be able to establish in Chicago something resembling the Collège de France, with a great deal of freedom both for the faculty members (in teaching and research) and the graduate students who participated (no course requirements for students at all) and who would necessarily be a rather small group." John Nef, 2I November 1943, Harold Innis Papers, Toronto, University of Toronto Archives, A76-0025, Box 12, File 45. Innis' address at the Collège de France in 1951, "Monopoly and Civilization," was published by Carpenter, McLuhan, et al. in Explorations 3 in 1953. See William Buxton, "Harold Innis' 'French Inflection': Origins, Themes, and Implications of His 195I Address at le Collège de France," Canadian Journal of Communication, vol. 29, 2004, p. I7I-I86.

Is Philip Marchand, Marshall McLuban: The Medium and the Message, Toronto, Random House, 1989, p. 98-99.

${ }^{16}$ Norbert Wiener, Cybernetics: Or Control and Communication in the Animal and the Machine, New York, The Technology Press, John Wiley and Sons, 1948, p. 9.

${ }_{17}$ "Cities That Survive the Bomb," undated draft, Norbert Wiener Papers, Boston, MIT, Box I2, Folder 638. Cited in Reinhold Martin, The Organizational Complex, Cambridge, MA, MIT Press, 2005. See also Norbert Wiener, Karl Deutsch, and Giorgio de Santillana, "How US Cities Can Prepare for Atomic War: MIT Professors Suggest a Bold Plan to Prevent Panic and Limit Destruction,” Life, I8 December 1950, p. 76-86. 
me to envisage an experiment in communication.” ${ }_{18}$ A month earlier, McLuhan had written Harold Innis to criticize the very same "Deutsch-Wiener approach [in] its failure to understand the techniques and functions of the traditional arts as the essential type of all human communication," but that he had been considering an "experiment in communication [...] in suggesting means of linking a variety of specialized fields by what might be called a method of esthetic analysis of their common features." I9 In his "pamphlet" on communication, however, Deutsch outlined an analysis of historical "breakdowns in communication" that currently threaten the growth of science and knowledge. Referring to Arnold J. Toynbee's investigations of "internal breakdowns in many civilizations of the past," ${ }^{20}$ Deutsch argues that the growth of

science depends on a continuing three way flow and re-flow of information: technical, between men and physical operations; social, between men and men; and intellectual, between a man's unanalyzed experiences and his ensemble of secondary symbols derived from them for conscious analysis and recombination, and between his own knowledge and the accumulated knowledge of men before him. Each of these three depends on a set of channels of communication of some kind; and it appears that the breakdown or loss of any one of these three classes of communication can destroy the growth of science. ${ }^{21}$

Placing greater emphasis on the history of communication than Toynbee, Deutsch's analysis of channels and breakdowns, and what he cites as the "growth of secrecy" and the "monopolization of organized knowledge by bureaucratic castes," clearly reverberates with Harold Innis' concern with monopolies of knowledge in Empire and Communications, ${ }^{22}$ published the same year.

\footnotetext{
${ }^{18}$ Marshall McLuhan to Norbert Wiener, 28 March 195I, Norbert Wiener Papers, Boston, MIT Archives, File 135, Box 9.

19 Letters of Marshall McLuban, Matie Molinaro, Corinne McLuhan, and William Toye (eds.), Toronto, Oxford University Press, 1987, p. 222-223.

${ }^{20}$ Arnold J. Toynbee, A Study of History, New York, Oxford University Press, 1934-196I, I2 vol.

${ }^{21}$ Karl W. Deutsch, "Higher Education and the Unity of Knowledge," in Lyman Bryson, Louis Finkelstein, and R. M. MacIver (eds.), Goals for American Education: gth Symposium, New York, Harper, 1950, p. 89.

${ }^{22}$ Harold Innis, Empire and Communications, Oxford, Clarendon Press, 1950.
} 
For his part, Carpenter brought a broad range of scholars from the world of anthropology, archaeology, and ethnography to the attention of the group. His connections particularly with the University of Pennsylvania, where he completed his $\mathrm{PhD}$ on the prehistory of Northeast Indigenous cultures in 1950 under the tutelage of Frank Speck, himself a student of Franz Boas, became valuable contributors to the journal Explorations. As Carpenter determined his interests, he moved squarely towards a cultural interest most strongly focused on art, theatre, and performance: the hallmarks of Boasian cultural anthropology. Over the life of Explorations, Carpenter would solicit contributions from other anthropologists who had studied under Speck, including Anthony F. C. Wallace, Melfrod Spiro, and A. Irving Hallowell, and from the broader anthropological community (among others, Dorothy Lee and David Bidney). In fact, with regard to the spoof cover of Explorations 2, "New Media Changing Spatial and Temporal Orientation to Self" Carpenter wrote Hallowell on 20 January 1954, "we're having a lot of fun designing the cover around your article ["The Self in Its Behavioral Environment"].” ${ }_{23}$ Hallowell's article, first published in the April 1954 issue of Explorations, would be integrated into his 1955 volume Culture and Experience.

McLuhan and Carpenter cunningly drew these many threads together for their proposal to the Ford Foundation. In a four-page draft of their proposal, they first describe Innis' studies of the American Revolution as a "clash between two networks of communication" before arguing—echoing Deutsch—that

the ideal approach to the quest for interdisciplinary rapport is to be found in a multifaceted study of the character of current conditions of communication. The relative breakdown of communication within the modern university is not something that began in the university. But it may well be that the mending of this state of affairs must begin at the university where the necessary habits of inspection and detachment coexist with the historic sense. ${ }^{24}$

In the final version of the proposal submitted to the foundation, the applicants expanded on this line of inquiry:

${ }^{23}$ Edmund Carpenter to A. Irving Hallowell, 20 January 1954, Alfred Hallowell Papers, The American Philosophical Library, Pittsburgh, Pennsylvania, no. 26, Series I.

${ }^{24}$ H. Marshall McLuhan Fonds, LAC, MG 3I, D 156, Volume 204, File 26. 
It is precisely this possibility of new patterning by juxtaposition of existing knowledge which the current administration of university departments and faculties makes difficult. That is what is meant by "the breakdown of communication within the modern university." Not only does the university largely fail to communicate with society at large, but its members do not share a common life. The obsession with spatial communication and control in society at large violates the integrity of the university community as well. For this reason alone interdisciplinary projects may be said to act as pilot studies in retracing the course. ${ }^{25}$

From the outset, one goal of this research initiative was to respond to the question of whether "arts" are indeed becoming "once more united" - to identify new points of convergence across the arts facilitated by the conditions of new media, and to question whether these conditions have renewed otherwise dormant forms of creative expression. As they would write in the Ford proposal,

[t] he approach to the cultural and social network as itself a work of human art has been signally successful in the work of Burckhardt and Siegfried [sic] Giedion. But today when unlimited physical power has brought the entire global environment, social and physical, within the scope of man's factive and artistic sense, it would seem to be more than ever timely to draw upon the reservoir of artistic wisdom in solving new problems and creating new vision. ${ }^{26}$

To comprehend the new "language of vision" provided by the increasing mechanization of visual experience (not coincidentally gesturing to György Kepes' 1944 Language of Vision), ${ }^{27}$ they required an "orchestration of diverse techniques," extending the Sapir-Whorf model to observe the new languages of new media themselves "through the combined analysis of the interplay between the visual and the oral at a personal, social, institutional, and cultural level.”28

\footnotetext{
${ }^{25}$ Carpenter et al., I953, p. I.

${ }^{26}$ Ibid., p. 5 .

27 György Kepes, Language of Vision, Chicago, Paul Theobald, 1944.

${ }^{28}$ Carpenter et al., 1953, p. 3-4.
} 
Jaqueline Tyrwhitt's experience at navigating interdisciplinary projects was invaluable. In early 1953 , as the group flirted with the new Ford programme proposal as an opportunity to build on the legacy of Innis' communications studies, she noted that "this all sounds a bit like Giedion's Faculty of Inter-Relation," 29 and reported to Giedion that "there is a short meeting at McLuhan's house at two about a Ford Foundation fellowship. I rather think it is going to be offered to you and that is why I am asked to be there." 30 The Ford proposal represented Tyrwhitt as a "pioneer of interdisciplinary studies in Britain" who has worked with Giedion "specifically on the problem of interdisciplinary study in the university and [who] came to Toronto especially to advance this kind of cooperation between the departments of economics, political science, sociology, social work, anthropology, architecture, and town planning." ${ }^{1}$ Ultimately, it was Tyrwhitt's own experimentation with the mediated character of urban environments, placing an emphasis on our emotional responses to urban design, that had the widest influence on the group's approach to urban space. ${ }^{32}$

\section{EXTENSIONS INTO EXPLORATIONS}

Upon receiving the Ford grant, McLuhan and Carpenter moved swiftly to establish plans for a magazine or journal as a media form that was appropriate for collecting universal approaches to studying new media. On 24 July 1953, McLuhan wrote to Tyrwhitt (who had then undertaken a year-long, UN-sponsored project to develop an exhibition on low-cost housing in India) that "Carpenter is keen to start a mag in connection with the project. So we are exploring possibilities." 33 By $28 \mathrm{July}$, W. R. Keast, a professor of English at Cornell University and member of the Ford program's Advisory Committee, wrote to program director Bernard Berelson about a letter he had received from McLuhan about their plan "to start a journal, to be called

${ }^{29}$ Jaqueline Tyrwhitt to Sigfried Giedion, II January 1953, Jaqueline Tyrwhitt personal archive, Box 4, Royal Institute of British Architects [hereafter RIBA], London.

${ }^{30}$ Ibid., i8 February 1953.

${ }^{31}$ Carpenter et al., p. 9-10.

${ }^{32}$ See Darroch, 2008; Darroch and Marchessault, 2009, p. 22-24; Michael Darroch and Janine Marchessault (eds.), Cartographies of Place: Navigating the Urban, Montréal and Kingston, McGill-Queen's University Press, 2014, Culture of Cities Series, p. 7-Io.

${ }_{33}$ Marshall McLuhan to Jaqueline Tyrwhitt, 24 July 1953, Jaqueline Tyrwhitt Papers, RIBA, TYJ $\backslash 8 \backslash 2$. 
Explorations, to publish contributions by various people from various places on the general problems of language, behavior, communications." 34 McLuhan had reached out to Keast for an opinion "on whether the Division and the Foundation would be receptive to an application for a small addition to their grant $-\$ 2500$ a year for two years." The two also hatched a plan to form a "discussion group on this communication business and study of literature for this year's Modern Language Association meeting," and indeed at the MLA in December 1953 McLuhan led a discussion entitled "A Role for English in the New Field of Communication Study." 35 Berelson initially responded (3o July) to Keast that "as for Toronto, I'm afraid not. Support for publications isn't very favorably received down here.” In October 1953, however, the tides turned. Claude Bissell, then Vice-President of the University of Toronto and a fellow English scholar, intervened to explain that "certain economies" had been effected, including the group's forgoing of a secretary, which would allow them to "subsidize publication." Bissell enquired with Berelson about "the general attitude of the Foundation towards the use of their funds for this particular purpose," to which Berelson responded with a series of questions about the character of the media form appropriate to the problem: " $[\mathrm{I}] \mathrm{s}$ it proposed to issue a separate printed series of the reports prepared by the seminar or is it simply a matter of mimeographing such reports for submission to interested colleagues? Or another question: Is it inappropriate to publish such reports in the normal scholarly channels?” (4 November 1953). Berelson requested that the group provide more information before he could offer a definitive answer. Bissell quickly responded with a brief prepared by the applicants. This brief explains their proposal "to print a series of small booklets, each containing separate but related papers, in some cases built around either figures (e.g. Innis, Giedion) or subjects"-figures constituting "pioneers in the analysis of non-verbal communication." The series was initially planned as six issues, three yearly during the life of the grant. As a rationale for the publication, the brief argues that the series could elicit "a fuller co-operative response" and "put the activities of students especially on a professional level," maintaining the "interdisciplinary approach basic to the whole project," as opposed to publications in scattered journals, and making the series an "integral part of the seminar.” Essentially,

34 FFA PA 53-70, Section 4.

35 "Conference 8: A Role for English in the New Field of Communication Study. Discussion leader, H. M. MCLUHAN, St. Michael's Coll., Univ. of Toronto,” Proceedings of the Modern Language Association of America, vol. 69, no. 2, April I954, p. 2I. 
"ARTS ONCE MORE UNITED":

BRIDGING DisCiplines THROUGH CREATIVE

MEDiA RESEARCH, 1955-1957

Explorations would "extend the range of the seminar on the campus and beyond it." On 17 November 1953, Berelson transmitted to Bissell the Foundation's conclusion that "we should more appropriately leave this decision up to you." ${ }_{6} 6$

The group also sought financial support from the Canadian Social Science Research Council. In a voice that seems to be Carpenter, the application explained that there was a shared desire to create a Canadian journal of anthropology and, having received the Ford Foundation grant, to "conduct a two-year interdisciplinary seminar, particularly in the fields of communications and anthropology, we felt our group might serve as the formal group to launch the desired journal.” The journal would be a new outlet and feedback mechanism to "stimulate more and better articles, above all which will explore new fields, set trends, and communicate findings among that growing body of Canadians who are turning to anthropology and communications as new approaches to human relations." In a "Tentative Outline" Carpenter indicated that the journal was to be named Explorations: A Canadian Journal of Anthropology and Communication. ${ }^{37}$ The journal's final masthead would declare that Explorations

is designed, not as a permanent reference journal that embalms truth for posterity, but as a publication that explores and searches and questions.

We envisage a series that will cut across the humanities and social sciences by treating them as a continuum. We believe anthropology and communication are approaches, not bodies of data, and that within each the four winds of the humanities, the physical, the biological and the social sciences intermingle to form a science of man.

Explorations was not the only project in the postwar period that sought to bridge disciplinary boundaries through universalist approaches. One specific influence on Explorations was the short-lived journal trans/formation: art, communication, environment (1950-52) (see Fig. 3), initiated by New York-based artist Harry Holtzman and which named both Giedion and Tyrwhitt among its many consulting editors. Indeed, Explorations' masthead tellingly borrowed part of trans/formation's title page, which announced that it "affirms that art, science, technology are interacting components of the total human enterprise...

\footnotetext{
${ }^{36}$ FFA 53-70, Section 4.

37 H. Marshall McLuhan Fonds, LAC, MG 31 Di56, Volume 203, File 30.
} 
[trans/formation] will cut across the arts and sciences by treating them as a continuum" (trans/formation I-3, 1950-2) - McLuhan and Carpenter notably swapped "arts" for "humanities." Like trans/formation, Explorations "was an effort to construct a community around the claim to universality." ${ }^{8}$ Carpenter and McLuhan sought to emulate trans/formation-McLuhan asked Tyrwhitt for "any essays of Transformations scope" or regarding her "India job and experience." 39 She would publish her contribution "Ideal Cities and the City Ideal" in Explorations 2 (April 1954), a paper that she had first drafted for the by then defunct trans/formation. $4^{\circ}$ Indeed, as Carpenter wrote A. Irving Hallowell on 9 June 1953 , "the closest thing to what we plan is probably Transformation." ${ }_{4} \mathrm{I}$

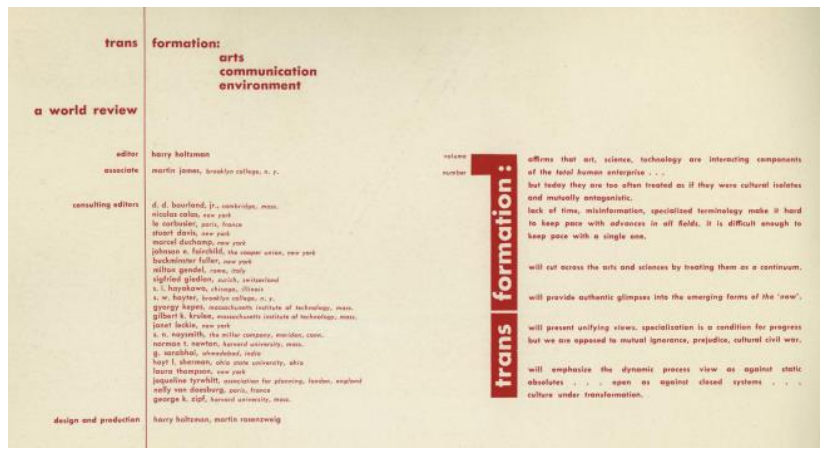

Fig. 3. Masthead of the journal trans/formation I (1950).

What is perhaps more important than the editors' predilection for borrowing mastheads was their quest to find the right template for a journal as a media extension of the seminar and grant. Tyrwhitt would become the most important figure in this regard through her connections to CIAM and other hubs of cross-disciplinary thinking. McLuhan and Carpenter similarly envisaged Explorations as an experimental mediator: a translator of ideas across disciplines and a means to connect with other groups studying communication, including those funded by Ford (Claude

${ }^{38}$ Anna Vallye, "The Strategic Universality of trans/formation, 1950-1952," Grey Room, no. 35, Spring 2009, p. 3I.

${ }^{99}$ McLuhan to Tyrwhitt, 29 October 1953, Jaqueline Tyrwhitt Papers, RIBA, TyJ \I8 $\backslash 2$.

$4^{\circ}$ Ellen Shoshkes, Jaqueline Tyrwhitt: A Transnational Life in Urban Planning and Design, Farnham, Surrey, UK, Ashgate, 2013, p. I67.

${ }^{4 \mathrm{I}}$ Carpenter to Hallowell, 9 June 1953, Alfred Hallowell Papers, American Philosophical Society, Philadelphia, Coll. 26 Series I. 
"Arts OnCE More United":

BRIDGING DisCiplines THROUGH CREATIVE

MEDiA RESEARCH, 1955-1957

Bissell asked Berelson in early July 1953 if it would be possible to set up "a sort of switchboard which would enable these various groups to exchange information and insights." 42 Explorations was devoted to developing a pedagogical approach to studying contemporary convergences between art, culture, science, and technology. While disagreements occurred, the group was guided by the conviction that the postwar new media environment necessitated a new field of study, that new methodologies must be involved.

\section{EXPERIMENTS IN MEDIA AND PERCEPTION}

Dialogue and playful experimentation characterized the environment of the Culture and Communications Seminar think-tank from the outset, an early foray in research-creation practices in Canada. The mischievous newspaper pages of Explorations 2 exemplified the experimental character of the project.

As mentioned above, blanketing the inside and outside, front and back covers (see Fig. 4 and 5), the unlikely newspaper carried the title Feenicht's Playbouse (or the Phoenix playhouse), gesturing to open-ended creative performance in Joyce's Finnegans Wake. ${ }^{43}$ As McLuhan would write in "Notes on Media as Art Forms" (Explorations 2), Joyce himself provided a model of pedagogical art to test out new media and communication forms: "Joyce was the first to exploit the multiple revolution of telegraph, press, radio, cinema, and TV. Finnegans Wake has already begun to appear as an orchestration of all media of communication." ${ }^{44}$ The front cover's headline proclaims "New Media Changing Temporal and Spatial Orientation to Self," and is accompanied by an amalgam of hoax articles drawing attention to the rapidly changing media environment, political climate, and artistic scene of the 1950s,

${ }^{42}$ FFA: PA 53-70, Section 5 .

43 James Joyce, Finnegan's Wake [1939], London, Faber \& Faber, 1964, p. 219.

${ }^{44}$ McLuhan relates Joyce's creations in ways that recount the very premise of the Culture and Communications Seminar: "The very process of human communication, Joyce saw, would afford the natural base for all the future operations and strategies of culture. Towards this vivisectional spectacle of the human community in action we have been led ever more swiftly in recent decades by increasing self-consciousness of the processes and effects of the various media of communication. Our knowledge of the modes of consciousness in pre-literate societies together with our sense of the processes of culture formation in many literate societies past and present, have sharpened our perceptions and led to wide agreement that communication itself is the common ground for the study of individual and society. To this study Joyce contributed not just awareness but demonstration of individual cognition as the analogue and matrix of all communal actions, political, linguistic and sacramental." Marshall McLuhan, "Notes on The Media as Art Forms," Explorations 2, April 1954, p. 9. 
"ARTS ONCE MORE UNITED":

BRIDGING DisCiplines THROUGH CREATIVE

MEDiA RESEARCH, 1955-1957

including “Time-Space Duality Goes," "T.S. Eliot Flies Home,” and "Historic Time Comes to End." The centrally featured famously falsified image of US Senator Millard Tydings meeting with Communist leader Earl Browder during the 1950 election campaign is captioned "McCarthy's Photomontage of Communist Browder and Democrat Tydings Kills Senator Tyding's Politically.” On the back cover, the entry "Hams - Clams" notes that "TV has been desperate for live material ever since the miracle came to pass. But a camera is like a gun: it changes the climate in the room. In many it brings out the ham, in many it brings out the clam.” Three other images, however, gesture to the concomitant seriousness of the project to test out modes of cross-cultural comparison and contrast. In the central space on the back cover is found the photograph In the Shadow of the Capitol (ca. 1946) by social documentary photographer Marion Palfi (albeit without credit), featuring three African-American girls in a distressed Washington street scene, the dome of the Capitol Building visible in the background (Palfi's image is also featured in the first issue of trans/formation, p. 43, followed by Piet Mondrian's 1926 essay “Home - Street - City”). On the inside front cover, a 1944 Marine Corps photo of US soldiers jitterbugging in front of a crowd of smiling Indigenous community members and fellow marines in Talasea, West New Britain, Papua New Guinea (an image also featured in trans/formation I, p. I4). And on the inside back cover, an advertisement for one of the first $3 \mathrm{D}$ feature films, Arch Oboler's Bwana Devil (1952) featuring "Natural Vision," at Toronto's

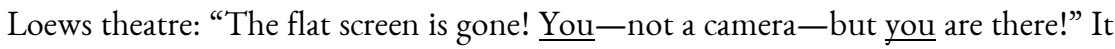
is worth keeping in mind that the qualities of ${ }_{3} \mathrm{D}$ film may well have been related to the group by Jaqueline Tyrwhitt, who had worked with Canadian architect Wells Coates in London. In 1951, Coates had designed one of the first ${ }_{3} \mathrm{D}$ cinemas, the Telekinema, for the Festival of Britain - a milestone in both live film and television broadcasting. ${ }^{45}$ The covers of Explorations 2 thus suggest that the all-pervasiveness of new media have transformed all cultural contexts into open laboratories-into classrooms without walls.

${ }^{45}$ See Janine Marchessault, Ecstatic Worlds: Media, Utopias, Ecologies, Cambridge, MA, MIT Press, 2017, p. 87-I25. 


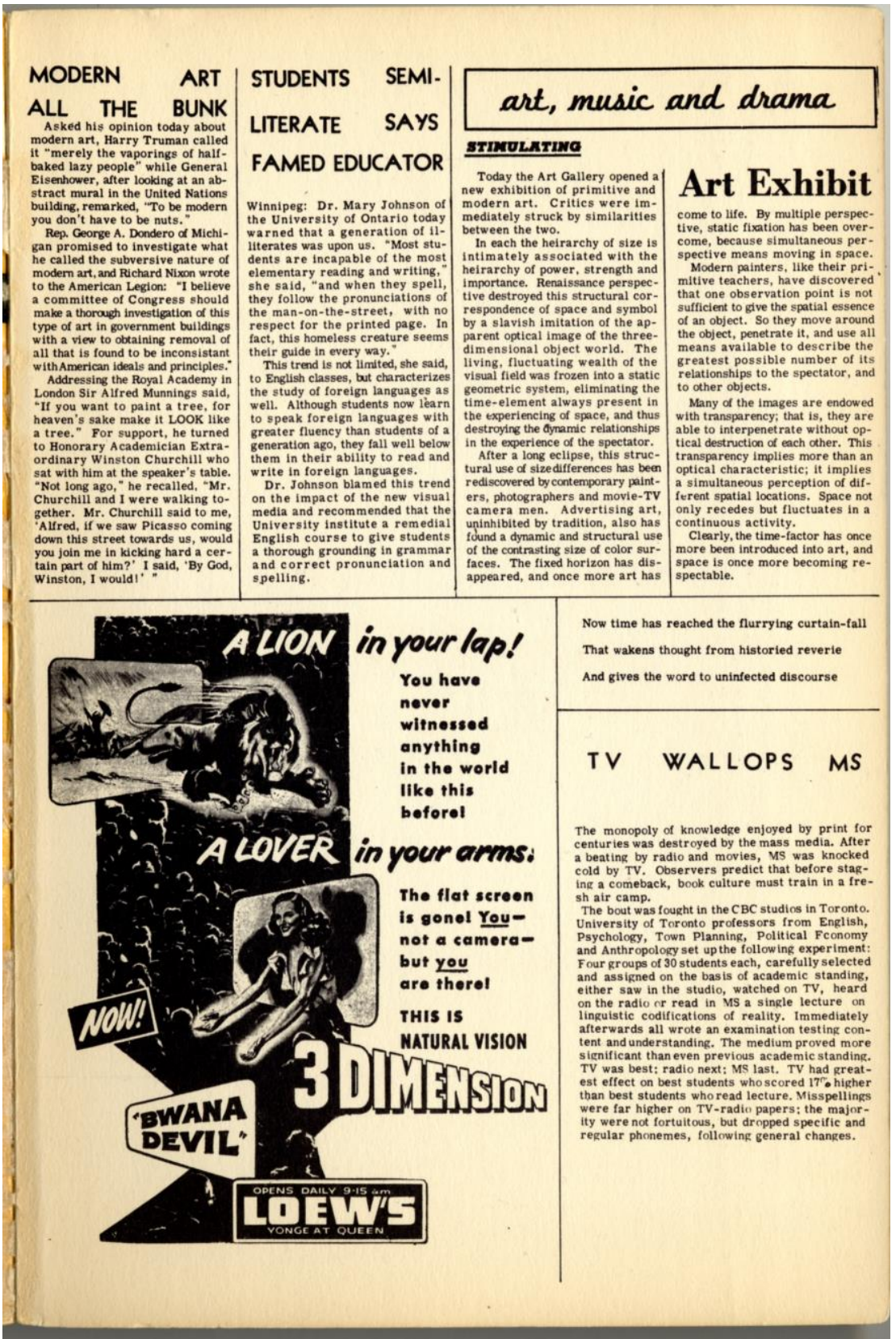

Fig. 4. Inside back cover of Explorations 2 (April 1954). Courtesy of the Estates of Edmund Carpenter and Marshall McLuhan. 


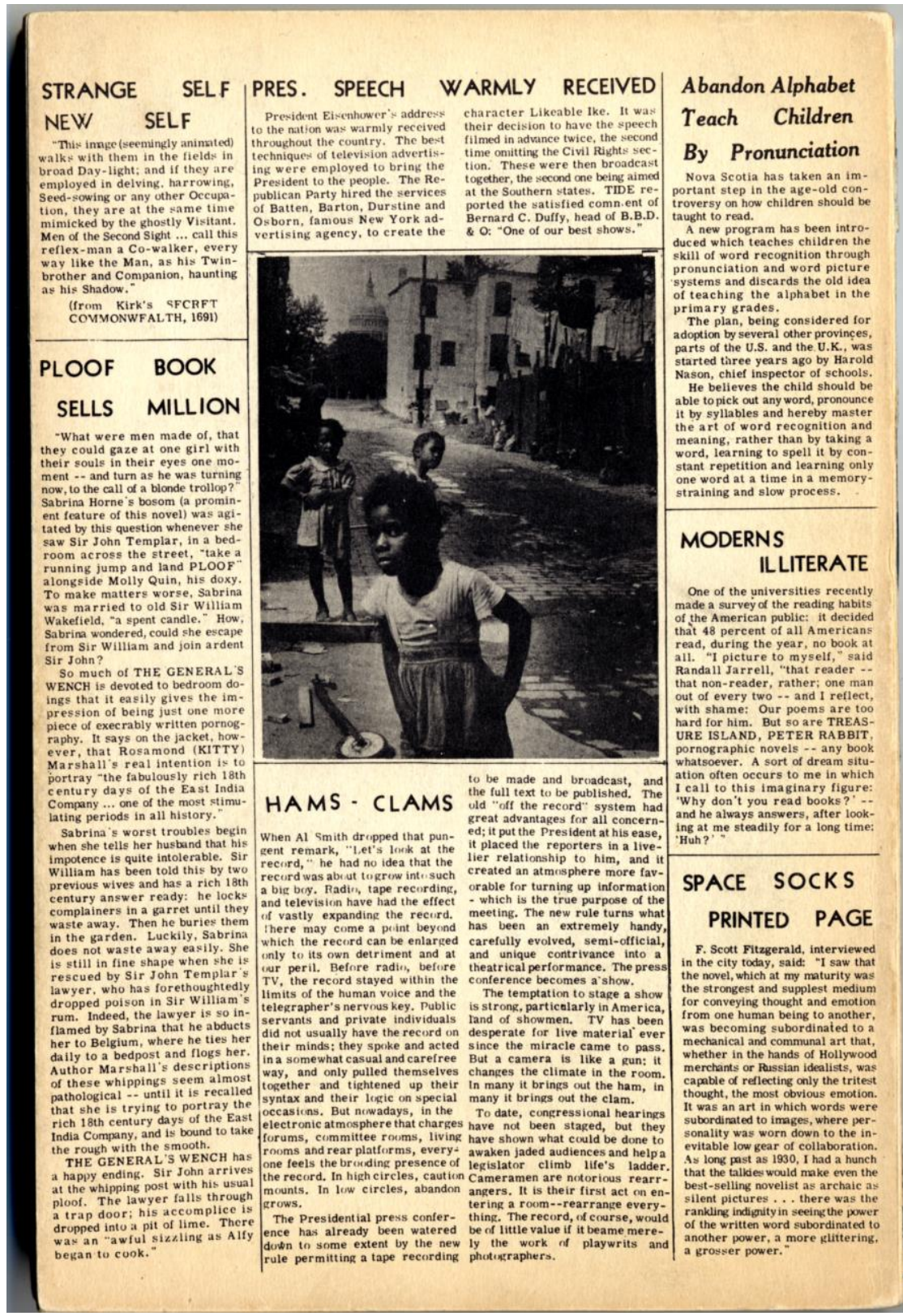

Fig. 5. Back cover of Explorations 2 (April 1954). Courtesy of the Estates of Edmund Carpenter and Marshall McLuhan. 


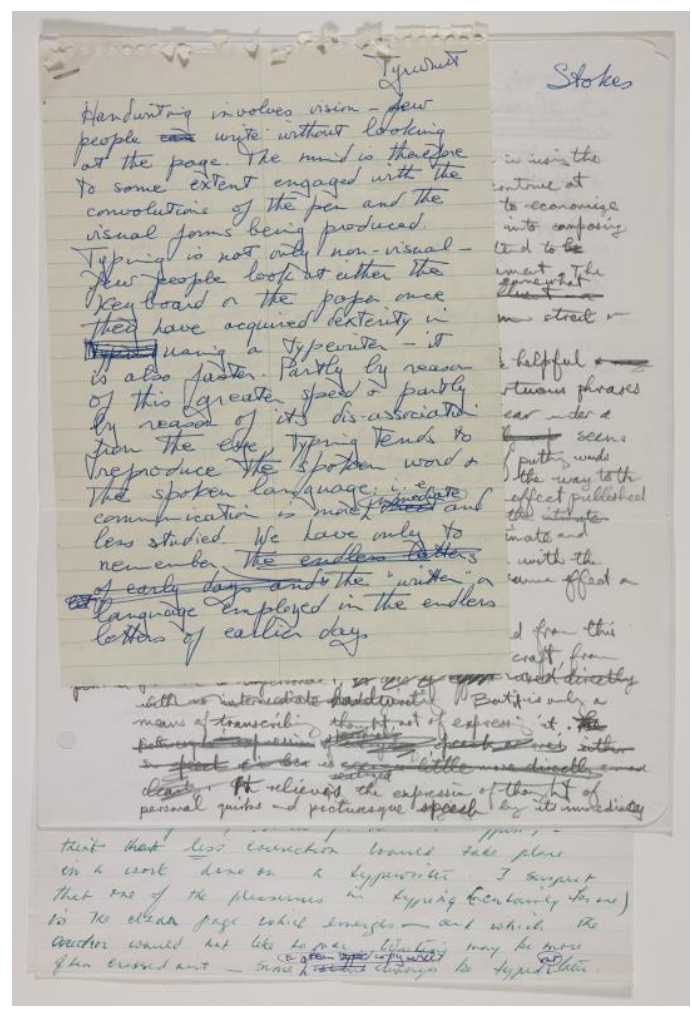

Fig. 6. Jaqueline Tyrwhitt's notes on the difference between handwriting and typewriting. Courtesy of Jaqueline Tyrwhitt Papers, Royal Institute for British Architects, TyJ $\backslash_{I 7} \backslash_{4}$, RIBA collections.

With cinema and TV on their minds, and to test hypotheses generated in class discussions and informal meetings about modes of perception in the context of a changing postwar media environment, they set about testing new and old media by acquiring "the antidote of related media like print," as McLuhan would later write about the typewriter. ${ }^{46}$ In order to copy excerpts and take minutes of their meetings, they purchased a Remington Rand typewriter, 47 and would engage in a robust discussion about the shift from writing to print. Doubts were expressed after one student proclaimed "the typewriter created a mechanical barrier between the writer

${ }^{46}$ Marshall McLuhan, Understanding Media: The Extensions of Man, New York, McGraw Hill Book Company, 1964, p. 287.

${ }_{77}$ The receipt is still preserved amongst Jaqueline Tyrwhitt's papers, RIBA, TyJ $I_{7} \backslash 4$. 
"ARTS ONCE MORE UNITED":

BRIDGING DisCiplines THROUGH CREATIVE

MEDiA RESEARCH, 1955-1957

and his work, and caused a short, staccato style," and participants were asked to submit reflections on this question. ${ }^{48}$ In her own response, Jaqueline Tyrwhitt captured the sentiment that McLuhan would later suggest in "The Typewriter: Into the Age of the Iron Whim," arguing "partly by reason of [its] greater speed + and partly by reason of its dis-association from the eye, typing tends to reproduce the spoken word + the spoken language: i.e. communication is more immediate and less studied.”

As the year progressed, seminar presentations became more provocative and the debates more raucous, a dialogue captured in the typeset minutes (prepared by Tyrwhitt, who worked as the Seminar's secretary in 1954/55): anonymous, diffuse, and non-linear amalgams of debated points and counter-arguments separated by ellipses are clustered at the end of later seminar meetings.

More formal experiments followed. Building on their hypothesis that the materialities of distinct media forms are ideally suited to carrying specific ideas or values, the group conducted a "media experiment" in the spring of 1954 at the CBC Toronto studios and later at Toronto's then Ryerson Institute of Technology. Carpenter crafted a script for the show entitled "Thinking through Language," which drew substantially on anthropologist Dorothy Lee's insights into linguistic codifications of reality. The lecture was presented to some izo students, divided into four groups who received it in person, on television, on the radio, or as a manuscript. The television portion was produced by none other than CBC's Sydney Newman, who allowed the group to try to shape a "neutral" show, to allow for comparison, rather than the most successful strategies of television production. After the $\mathrm{CBC}$ released a news bulletin, a New York Times headline captured the group's initial surprise at the results: "Video Best Teacher, Researchers Find"; "Television is a firstclass teacher, easily surpassing its elder cousin, radio." 49 Students who had participated in the television segment retained the most information, followed by the radio group, the reading group, and finally the studio/lecture hall group. In his review "Certain Media Biases," Carpenter interpreted the results in two significant ways. First, "[i]t became apparent from differences such as these, that it was not simply a question of communicating a single idea over various media, but that a given type of idea or insight belongs primarily, though not exclusively, to one medium, and

${ }^{8} 17^{\text {th }}$ meeting; 9 February 1955, see H. Marshall McLuhan Fonds, LAC, M3I Di56, vol. 203, File 30; see also Jaqueline Tyrwhitt Papers, RIBA, TyJ $\backslash_{17} \backslash_{4}$.

49 "Video Best Teacher, Researchers Find," New York Times, 5 March 1954, p. 26. 
that it can be gained or communicated best through that medium." 50 Second, with the televisual, Carpenter believed they had encountered a medium capable of reuniting the arts and overcoming the separation of thought and feeling (a schism that Giedion had long sought to overcome):

Now one of the results of the time-space duality which developed in Western culture from the Renaissance on, was a separation within the arts. Music, which created symbols in time, and graphic art, which created symbols in space, became separate pursuits, and men gifted in one rarely pursued the other. Dance and ritual, which inherently combined them, fell in popularity. Only in drama did they remain united. It is significant that of the four new media, the three most recent are essentially dramatic media, particularly television which combines music and art, language and gesture, rhetoric and colour. They convey emotional tones, not merely "information." They do not, however, exercise the same freedom with time that the stage practices. An intricate plot, employing flash-backs, multiple perspective, and overlays, intelligible on the stage, might be completely mystifying on the screen. ${ }^{5 \mathrm{I}}$

The group's psychologist, Carl Williams, would also analyze the results of the experiment, reporting that an experiment was performed on Io8 students to test the different effects of discrete mass media on learning. Williams was more hesitant to establish conclusions:

It is fair to conclude that media do make a difference in immediate recognition, using undergraduates as subjects. It is also fair to rank the media from television through radio to reading in terms of their effectiveness under these conditions. No conclusion is drawn on the studio group. At this stage of research, generalization is dangerous. The study does not prove that television is "better" than radio or that either is preferable to books, or that "live" audiences learn little. ${ }^{52}$

so Edmund Carpenter, “Certain Media Biases,” Explorations 3, August 1954, p. 65-74.

${ }^{51}$ Ibid.

52 "Mass Media and Learning - An Experiment," Explorations 3, August 1954, p. 75-82, italics in the original. With his then graduate students, he would report the findings again in the Canadian Journal of Psychology: D. C. Williams, J. Paul, and J. C. Ogilvie, "Mass Media, Learning, and Retention," Canadian Journal of Psychology, vol. II, no. 3, 1957, p. 157-163. 
"ARTS ONCE MORE UNITED":

BRIDGING DisCiplines THROUGH CREATIVE

MEDiA RESEARCH, 1955-1957

In an April 1955 letter to members of the seminar, likely in response to Williams' analysis, Carpenter chastised the group for misrepresenting the purpose of their media experiment conducted at the CBC studios. "My interest was media biases," he wrote, "I was convinced that the secret of TV was its extreme non-lineality, as opposed to the lineality of the book, so I decided to choose a subject associated with book culture but to present it non-lineally. Thus I hoped to achieve a 'neutral' show-and here I was mistaken, we now know, for the content, contrary to expectations, proved as much at home on TV." ${ }_{33}$ The final entry on the inside back cover of Explorations 2 captured the essence of this first media experiment for Carpenter and McLuhan. "TV Wollops MS," the entry reports: "The monopoly of knowledge enjoyed by print for centuries was destroyed by the mass media. After a beating by radio and movies, MS was knocked cold by TV. Observers predict that before a staggering comeback, book culture must train in a fresh air camp.”

Tyrwhitt, along with Williams, developed a plan to test student perceptions of the urban environment, a pedagogical program derived in part from a proposal for an "intracampus study" mentioned in correspondence between Tyrwhitt and McLuhan in early 1953. The "Perception and Use of the Environment" experiment was conducted before Christmas 1954 with students at Ryerson Institute of Technology. A questionnaire of 24 questions was distributed to some 900 students enquiring into their background and interests (especially their use of various media during the day and as pastimes), perceptions of their own movements in urban space and perceptions of the visual environment in the vicinity of Ryerson. The survey inquired into perceptions of urban structure and objects-street orientation, street furniture, trees, colours-city elements designed to attract their attention, chiefly advertising, and whether they found beauty in any aspects of their urban environment. 54 Faculty and graduate students worked to tabulate the results. Published in Explorations 5 (June 1955) and elsewheress as "The City Unseen," the study gestured to the group's emerging focus on the effects of forms of communication on knowledge systems, and their emphasis on using city spaces as learning environments. In 1956, Tyrwhitt would narrate a segment on the "City

${ }^{53}$ Jaqueline Tyrwhitt Papers, RIBA, TyJ $\backslash_{17} \backslash_{4}$.

${ }^{54}$ Jaqueline Tyrwhitt Papers, RIBA, TyJ $\backslash \mathrm{I} 8 \backslash_{\mathrm{I}}$; see Darroch, 2008.

5s Jaqueline Tyrwhitt, "The City Unseen," Architecture and Building, vol. 30, no. 9, September I955, p. 328-33I. 
Unseen" for an episode of CBC's television production Explorations on "The Unseeing Eye" (see Fig. 7)..$^{56}$

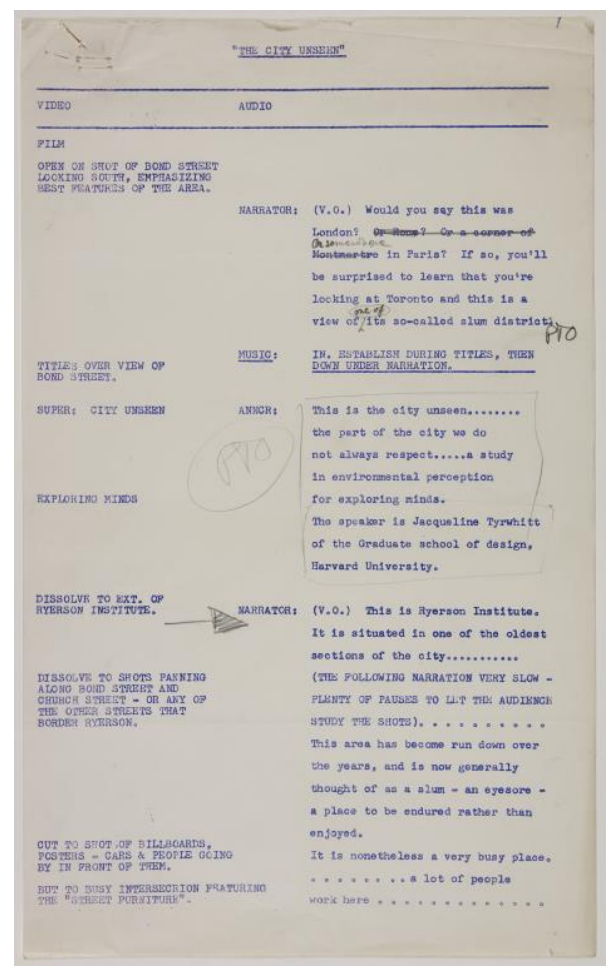

Fig. 7. Draft manuscript of the "The City Unseen," hosted by Jaqueline Tyrwhitt, for the CBC series Explorations' episode "The Unseeing Eye," broadcast 9 September 1956. Courtesy of RIBA Collections.

In many ways, the results became as much a study of the lack of perception of the environment. In their analysis, Tyrwhitt and Carl Williams concluded that there were two major levels of perception at play: "a very low level, a purely sensory level, at which the eye purely records impressions of colour and bulk"; and a second sensory level at which "only vague impressions are retained" such as silhouette and colour. After moving to Harvard, Tyrwhitt would conclude that "we really know very little about how to design so as to rekindle the interest of the public in their visual

${ }^{56}$ See manuscripts in Jaqueline Tyrwhitt Papers, RIBA, TyJ $\backslash_{\mathrm{I}} \backslash_{\mathrm{I}}$ and $\mathrm{Ty} J \backslash_{4} 8 \backslash 6$. 
"ARTS ONCE MORE UNITED":

BRIDGING DisCiplines THROUGH CREATIVE

MEDiA RESEARCH, 1955-1957

environment." ${ }_{7} 7$ Unlike the capacity of a film camera to record everything in front of it, the human eye and mind collected and recollected selectively; "imaginative vision" leaps "ahead of actuality." 88

\section{CONCLUSION}

The many dialogues and experiments that Explorations initiated are thus indicative of the ways in which intermedial studies became organized and institutionalized in the 1950s and 1960s, paving the way for future collaborations bridging the arts, humanities, and sciences. In a position that would resonate with McLuhan's sensibility of the performative qualities of language, and echoing Giedion's call to re-establish a "dynamic equilibrium” between thought and feeling, Carpenter came to argue that "only in drama did [the arts] remain united" and thus it was the dramatic qualities of live television that were unique in uniting both the senses and the arts: "The cameras lead the spectator from a total view to a close-up, and back again, creating a dynamic picture [...] closer to communicating an unabridged situation than any other medium and involves the direct give and take of a dynamic relationship.”59 Together, these scholars shared the belief that the new media environment necessitated the reunification of the arts through simultaneity and multisperspective, as reported in the covers of Explorations 2's Feenicht's Playhouse. In the upper right corner of the inside back cover, the "arts, music, drama" section reports that critics were struck by similarities between prehistoric and modern art forms: "Modern painters, like their primitive teachers, have discovered that one observation point is not sufficient to give the essence of an object." The result is the re-orienting of the time-space duality at the end of the dominance of written history: "Clearly, the time-factor has once more been introduced into art, and space is once more becoming respectable." Their conclusion was that "Historic Time Comes to End." To this point, Carpenter subtly included the opening lines of Laura Riding and Robert Grave's i930s journal Epilogue: "Now time has reached the flurrying curtain-fall / That wakens thought from historied reverie / And gives the word to uninfected discourse."

57 Jaqueline Tyrwhitt, "Across the Street," in Mosaic, Architectural Society of the School of Architecture, Toronto, University of Toronto, 1957, p. II.

${ }^{58}$ Ibid.

59 Edmund Carpenter, "Certain Media Biases," Explorations 2, April 1954, p. 66. 
Writing for the Chicago Review in 1956, in an initial report on their educational experiment entitled "The New Languages," Carpenter and McLuhan coannounced that "the new mass media-film, radio, television-are new languages, their grammars as yet unknown. Each codifies reality differently; each conceals a unique metaphysics." ${ }^{\circ 0}$ As the review's editor noted, "forced to reach beyond their own classroom walls the members of this Toronto seminar decided to publish a journal, Explorations, devoted to a study of media biases." ${ }^{61}$ Carpenter, McLuhan, and Tyrwhitt would incorporate the results of their Culture and Communications Seminar's experiments into their many future endeavours. McLuhan reproduced the results of the $\mathrm{CBC}$ experiment within his 1960 Project for Understanding New Media, and he would carry the group's insights into his preparatory work for both The Gutenberg Galaxy (1962) and Understanding Media (1964). The insights and examples that emerged from the discussions and experiments conducted by the group also accompanied Carpenter in his own approach to media anthropology, starting with his reorganization of the journal's format in Explorations 9 (1959), subtitled Eskimo, which juxtaposed his own writings with film stills by Robert Flaherty and paintings by Frederick Varley. Explorations 9 reflected Carpenter's attempt to capture the sense of multiperspective, of objects in motion, that he wished to portray the same year in an unfinished documentary film entitled Eskimo Art. In 1958, he wrote to Giedion, "in photograph and in layout we tried to reflect the spirit of Eskimo art: in motion, with multi-perspective. Thus we would take a single ivory carving, and with a black background, get various exposures, at different angles and distances, juxtaposing and superimposing." ${ }^{2}$ These themes resurface in his later publications They Became What They Bebeld (1970), Ob What a Blow That Phantom Gave Me (1972), and Eskimo Realities (1973). Carpenter left the University of Toronto in 1959 to initiate an experimental program bridging multiple arts and anthropology at San Fernando Valley State College in Northridge (1959-67). In 1968-69, he further participated in Fluxus artist Robert Watt's “Experimental Seminar” at the University of California at Santa Cruz. Together with Watts and others, and with support from the Carnegie Foundation, he would co-edit the volume Proposals for Art Education,

${ }^{60}$ Edmund Carpenter and Marshall McLuhan, "The New Languages," Chicago Review, vol. Io, no. I, Spring 1956, p. 46.

\footnotetext{
${ }^{61}$ Ibid., p. 52.

${ }^{62}$ Carpenter to Giedion, io November 1958, GTA, 43-K-1958-II-IO.
} 
published in 1970. ${ }^{63}$ For her part, Jaqueline Tyrwhitt joined Harvard's Graduate School of Design in 1955 and became, through to her death in 1983, the editor of Ekistics, a journal that extended the CIAM notion of "network" as a method of crossdisciplinary comparison. ${ }^{64}$ The scholarly network that took shape during these years of Ford Foundation funding at the University of Toronto thus laid the framework in Canada for initiatives in creative media research that have become fundamental aspects of arts and humanities education.

${ }^{63}$ Edmund Carpenter, Christopher Cornford, Sidney Simon, and Robert Watts (eds)., Proposals for Art Education, funded by the Carnegie Corporation, New York, 1970.

${ }^{64}$ See Mark Wigley, "Network Fever," Grey Room, vol. 4, 200I, p. 82-I22. 


\title{
“Arts Once More United”: Bridging Disciplines through Creative Media Research, Toronto, 1953-55
}

\author{
Michael Darroch, School of Creative ARTS, University oF \\ WINDSOR
}

\section{ABSTRACT}

From 1953 to 1955 , the Ford Foundation funded a unique experiment in intermedial study and experimentation at the University of Toronto. The Culture and Communications Seminar and the journal Explorations, led by Edmund Carpenter, Marshall McLuhan, and Jaqueline Tyrwhitt, are indicative of the ways in which intermedial studies became organized and institutionalized in the 1950s and 1960s. The scholarly network that took shape during these years of Ford Foundation funding laid the framework in Canada for initiatives in creative media research that have become fundamental aspects of arts and humanities education. This article charts the assemblage of geographic, disciplinary, artistic, and organizational connections that facilitated this educational experiment.

\section{RÉSUMÉ}

Durant les années 1953-55, la Ford Foundation a financé, à l’Université de Toronto, une expérience inédite d'études intermédiales. Le séminaire Culture and Communication ainsi que le journal Explorations qu'ont dirigés Edmund Carpenter, Marshall McLuhan et Jaqueline Tyrwhitt témoignent ainsi de l'organisation et de l'institutionnalisation des études intermédiales durant les années 1950 et 1960. Le réseau didactique qui prend forme dans l'orbe du financement de la Ford Foundation jette les bases de la recherche créative sur les médias, maintenant devenue un aspect fondamental des programmes d'éducation en arts et en sciences humaines. Cet article retrace les connexions géographiques, disciplinaires, artistiques et organisationnelles qui ont facilité cette expérience éducationnelle.

\section{NOTE BIOGRAPHIQUE}

Michael Darroch is Associate Professor of Media Art Histories and Visual Culture in the School of Creative Arts, University of Windsor. He was Founding Director (2010-16) and is now Co-Director of the IN/TERMINUS Creative Research Collective. He co-edited Cartographies of Place: Navigating the Urban (MQUP, 20I4), an interdisciplinary collection that situates different historical and methodological currents in urban media studies. Recent essays engage with histories of communication and media studies, urban media cultures, and borderlands studies. 
His research facilitated the republication of the eight collaboratively edited issues of the journal Explorations for which he co-authored a new introduction. 